\author{
Oleksii Lyulyov, \\ Ph.D., Associate Professor, \\ Sumy State University, \\ Sumy, Ukraine \\ Olena Chygryn, \\ Ph.D., Associate Professor, \\ Sumy State University, \\ Sumy, Ukraine \\ Tetyana Pimonenko, \\ Ph.D., Associate Professor, \\ Sumy State University, \\ Sumy, Ukraine
}

\title{
NATIONAL BRAND AS A MARKETING DETERMINANT OF MACROECONOMIC STABILITY
}

Modern tendencies of globalization and counties' competitiveness increasing make governments search absolutely new approaches and relevant tools to raise their competitive capacities. The research explains why marketing factors of the competitive strengths formation today have an urgent value for describing and substantiation marketing strategies of cities and municipalities, regions and territorial communities, countries as a whole. The purpose of the paper is to study the marketing factors of the country's competitive advantages and determine the influence of the national brand on the macroeconomic stability of the country. The authors checked the hypothesis of the correlation between country's brand (which perception by the non-residents) and macroeconomic indicators of the efficiency level of brand using by the country. With purpose to check abovementioned hypothesis authors developed two level approach. At the first level the authors proposed to estimate the performance of using brand by the country which take to account countries the competitive strengths of the country in the global environment, consisted from the composite indicators which allocated by the PESTLE method and could be quantitively evaluated corresponding to the international methodology. At the second level the authors estimated (using the Spearman's rank correlation coefficient) nonparametric statistical relations between country's brand perception by the non-residents (indicated by the FutureBrand methodology, which based on the quiz of the respondents' group: external investors, tourists, government of others country ant etc.) and economic performance of brand using by the government. The empirical proven of the hypothesis were made by the using of two data samples. The first dataset involved the ten strongest brands according to the rating of NBI since 2008. The finding confirmed the linear correlation between level of macroeconomic stability and strongest of the national brand for Germany, France and Canada. The base for the second dataset was information from the raiting SIE in EU and Ukraine for 2010-2015 years. The hypothesis was confirmed for Sweden, Germany, Finland, Denmark, Austria, the Netherlands, Croatia, Ukraine.

Keywords: brand, country image, competitiveness, sustainability, reputation of the country.

Introduction. Globalization enhances the processes of international competition not only at the companies level, but it is also giving them the opportunity for gaining additional competitive advantages and provide better development opportunities for their societies and countries. The new forms of competition compel managers at a different level (companies, countries) to seek more complicated methods of obtaining a competitive advantage especially in the field of intangible factors. The empirical studies indicate that more developed countries use dynamic marketing tools for finding new competitive advantages (Fetscherin, 2010). The particular significance in recent years has become the concept of the 
state brand, when the governments of the leading EU countries spend significant money on the promotion of their own brands (France - 3.1 billion dollars, Great Britain, Germany - 1.2 billion dollars) (The Global, 2016). In Ukraine, from 2015, the Strategy of Sustainable Development "Ukraine -2020" identifies a roadmap and four priority vectors of the national economy movement: the vector of development; security vector; liability vector; vector of pride (Sustainable, 2015). The vector of pride determines the necessity of creating the "Ukraine" brand in order to popularize the country, to build a sustainable competitive advantage and opportunities associated with the development of the national economy. Thus, the relevant question is studying the influence of the national brand on the level of macroeconomic stability, as one of the main tools for improving the competitiveness of the country.

Literature Review. In the most scientific studies, the marketing determinants of sustainability and stability are considered at the micro level, in other words, with respect to the economic entities. At the same time, during the last decades has appeared a separate scientific direction - marketing of cities and municipalities (Hankinson, 2001; Kotler and others, 1999; Morgan and others, 2002; Ward, 1998; Warnaby and others, 2002), marketing of regions and territorial communities (Murpy and others, 2007; Anholt, 2005), marketing of countries (Riege \& Perry, 2000; Anholt, 2007). The fundamental principles of the studing of national branding are laid down in the foreign and domestic works of S. Anholt (Anholt, 2005, Anholt, 2007), F. Kotler (Kotler, 1999; Kotler and Gertner, 2002), K. Dinny (Dinny, 2002), C. Belloso (Belloso, 2010), E. Jaffe (Jaffe, 2001), Fedoriv T.V. (Fedoriv, 2011), Tsygankova T.M. (Tsygankova, 2011), Yaremko Z.M. (Yaremko, 2016).

Within the limits of this scientific direction, the objects of the research are, first and utmost, the brand, reputation, cultural and national identity, and the image of territorial entities. In Ukrainian scientific literature, these studies are rather analytical and descriptive, while the foreign studies have economic and mathematical models for their evaluation.

The practice of building countries brand rating has already quite widespread in the world (they compiled by GFK, FutureBrand, The Bloom Consulting, Brand Finance, East West Communications, etc.). But there are the main methodological problems in their formation: 1) the disclosure by the agencies the mechanisms of the calculation of a relevant index; 2) subjectivity of ratings (separate ratings are based solely on the results of the different target groups); 3) dependence of the country's brands rating from the number of countries accepted for evaluation (only in a few countries such surveys are conducted according to a single methodology); 4) do not take into account the economic efficiency of using the country of its brand.

The American Marketing Association defined the brand as "name, term, sign, symbol, design or a combination of them, intended to identify the goods and services of one seller or group of sellers and their differentiation from competitors" (Hanna, 2008). In the vast majority of scientific works, the concept of the brand at the enterprise level primarily has financial and legal features. For example, Italian researchers in their work, "An AHP approach to assess brand intangible assets" indicated that brands are defined as intangible assets, that along with other assets of an enterprise, provide it competitive advantage (Costa, 2008). This view assumes that brands should be managed and accounted for as appropriate corporate assets (Wood, 2000). In turn, Rassomakhina (2007) exploring the definition of "trademark", "brand" concluded that the first two concepts describe the brand as intangible companies' asset, which is legally enshrined in them, determine their property rights and serve as the basis for the brand creation. Considering the methodological aspects of the definitions of "trademark", "brand", "goodwill" V. Krykun (2010) also observes that "trademark" is only a basis for a brand, which additionally must be considered "... it is the level of popularity among buyers, the quality of goods or services, reputation, stability " (Krykun,2010). Lane Keller defines the brand as a resonance in customer decisionmaking, which is a result of their reaction to marketing signals from companies (Keller, 2003).

The purpose of the article is to study the marketing factors of the country's competitive advantages 
and determine the influence of the national brand on the country's macroeconomic stability.

Research results. The analysis of modern experience shows that the methodology of constructing the countries brands rating is developed on the basis of the hierarchical decision model. This allows determining the degree of target audience relevance (residents, investors, governments of other states, tourists) of the analyzed country's brand. The main dimensions of the target audience communications with the brand of the country there are the quality of life, value system, business climate, heritage and culture, as well as tourism (Lyulyov, 2016).

Since 2005, Gfk, together with S. Anholt (2005), has been calculating the Nation Brand Index (NBI), which is based on the assessment of perception by selected countries of provided research by residents of other countries. The testing is conducted in countries where The Gfk represented among the population over the age of 18 , taking into account the gender and the level of education, which provides an opportunity to provide a representative sample. According to the report of 2016, the first positions in the world ranking of the strongest national brands were kept by USA, Germany and the UK. Overall last three years the ten strongest national brands remained unchanged (Table 1).

Table 1 - Ranking of the strongest national brands during 2014-2016 (The Global, 2016)

\begin{tabular}{|l|c|c|c|c|c|c|}
\hline \multirow{2}{*}{ Country } & \multicolumn{7}{|c|}{ Ranking } & $\begin{array}{c}\text { Changes in 2016 compared to } \\
\mathbf{2 0 1 4 / 2 0 1 5}\end{array}$ \\
\cline { 2 - 7 } & $\mathbf{2 0 0 8}$ & $\mathbf{2 0 1 0}$ & $\mathbf{2 0 1 4}$ & $\mathbf{2 0 1 5}$ & $\mathbf{2 0 1 6}$ & \\
\hline USA & 7 & 1 & 2 & 1 & 1 & $\uparrow 1 /-$ \\
\hline Germany & 1 & 2 & 1 & 2 & 2 & $\downarrow 1 /-$ \\
\hline Great Britain & 3 & 4 & 3 & 3 & 3 & $-/-$ \\
\hline France & 2 & 3 & 4 & 4 & 5 & $\downarrow 1 / \downarrow 1$ \\
\hline Canada & 4 & 6 & 5 & 5 & 4 & $\uparrow 1 / \uparrow 1$ \\
\hline Japan & 5 & 5 & 6 & 6 & 7 & $\downarrow 1 / \downarrow 1$ \\
\hline Italy & 6 & 7 & 7 & 7 & 6 & $\uparrow 1 / \uparrow 1$ \\
\hline Switzerland & 8 & 8 & 8 & 8 & 8 & $-/-$ \\
\hline Australia & 9 & 9 & 9 & 9 & 9 & $-/-$ \\
\hline Sweden & 10 & 10 & 10 & 10 & 10 & $-/-$ \\
\hline
\end{tabular}

At the same time, the largest strengthening of the national brand since 2008 was made by the United States. It explaining by the recovering of the country's economy after a major financial and economic crisis. Ukraine until 2016 wasn't ranked, which makes it impossible to use this index for analyzing the impact of its level on the macroeconomic stability of the state. In addition, one of the limitations of the used methodology is using only the opinion of another countries resident, which gives to the study a subjective character.

The FutureBrand Company providing more scaling analysis of the country's brand evaluation (102 countries were included in the ranking, twice as much as Gfk estimates) (The Global, 2016). The company's specialists point out that the Country Brand Index (CBA) calculates, on the one hand, an idea of the country's own position compared to other states, and on the other, it has an advisory nature and helping to show which areas need urgent recovery or changing a strategy aimed at increasing the strength of the brand.

According to the 2014-2015 SBS rating report, six European countries (Switzerland - 2, Germany 3rd place, Switzerland - 4th place, Norway - 6th place, Denmark - 9th place, Austria - 10th place) were ranked and were included into to the ten most powerful global brands. Ukraine ranks the last place in the ranking (74th place) among all studied European countries, which reflecting the development of the national economy (Figure 1). 


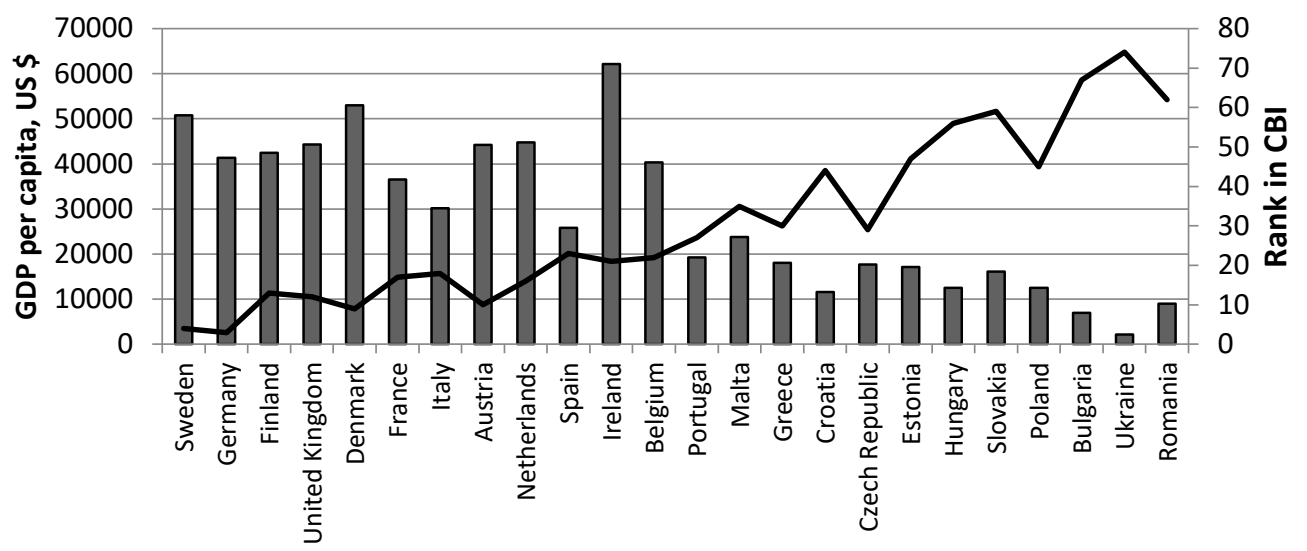

Figure 1 - Correlation of ranking by SVI and GDP per capita in Europe in 2015 (The Global, 2016)

Under this researching the authors proposed to use two level approach (figure 2) for estimating the efficiency of the brand using by countries. The proposed approach takes to account the competitive strengths of the country compare to the whole countries in the world (not only for few countries). According to the Kotler (Kotler et al., 2002) and Anholt (1995) which are founder of marketing theories, proposed to estimate country's brand according to the main principles which used for companies' brand estimation. Thus, the country's brand was estimated using the composite indicators which allocated by the PESTLE method and could be quantitively evaluated corresponding to the international methodology. With purpose to eliminate the unstable short-term changes in dynamic of the country's brand as a consequence of political and economic imbalance the authors estimated the post-evaluation estimations of long time period.

\section{LEVEL 1}

The developing of system of $j$ indicators to estimate the economics results of brand using $i$ country $\left(M C B l_{i j}\right)$

$\mathrm{E}$ - the exports of goods and services, US $\$ ; F$ - volume of direct international investments, US $\$ ; T$ - the number of international tourists in the country; $\mathrm{M}$ - the number of international migrants in the country; WGI - the effectiveness of political institutions in the country; TP - the level of technological readiness of the country for economic transformations (component of the Global Competitiveness Index), Ec - the country's Environmental Performance Index (ES); $x_{i}-$ quantitative of $i$ country, $\overline{M C B I x_{1}}$ - the average of $j$ indicators for analysing period, $\sigma$-standard deviation of $j$ indicator of the country for analysing period

\begin{tabular}{|c|c|}
\hline \multicolumn{2}{|c|}{ Normalized indicators (eliminate the factor of country size) and comparable view } \\
\hline$M C B I_{x_{i j}}=M C B I_{i j} / x_{\mathrm{i}}$ & $\begin{array}{l}\text { Eliminate the country size for indicators } \boldsymbol{E}, \boldsymbol{F}, \boldsymbol{T}, \boldsymbol{M} \\
\qquad N=\left(M C B I_{x_{i j}}-\overline{\left.M C B I_{x_{j}}\right)} / \sigma\right.\end{array}$ \\
\hline
\end{tabular}

Aggregating the Normalized indicators $M C B I_{i}$ (formula 1)

LEVEL2

Analysis of the nonparametric measure of statistical dependence between the country brand assessment by FutureBrand (CBI) and $\mathrm{MCBI}$ across the entire country sample (formula 2)

Figure 2 - Two level approach to estimate the efficiency of the brand using by countries 
Thus, the normalized countries brand could be estimated by the formula 1 .

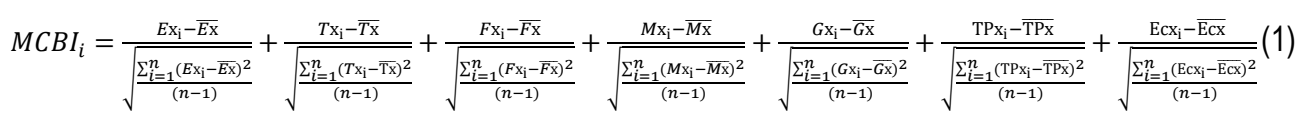

where $\mathrm{E}$ - the exports of goods and services, US $\$ ; \mathrm{F}$ - volume of direct international investments, US $\$ ; T$ - the number of international tourists in the country; $\mathrm{M}$ - the number of international migrants in the country; WGI - the effectiveness of political institutions in the country; TP - the level of technological readiness of the country for economic transformations (component of the Global Competitiveness Index), Ec - the country's Environmental Performance Index (ES) table 2.

The fragment results of countries brand estimation by the above-mentioned approach showed in the

Table 2 - Rating of the countries' brands using the $\mathrm{MCBI}_{\mathrm{i}}$ (Developed by authors)

\begin{tabular}{|l|l|l|l|l|l|}
\hline Year & \multicolumn{1}{|c|}{ 1 place } & \multicolumn{1}{c|}{ 2 place } & \multicolumn{1}{c|}{ 3 place } & \multicolumn{1}{c|}{ 4 place } & \multicolumn{1}{c|}{$\mathbf{5}$ place } \\
\hline $\mathbf{2 0 0 0}$ & Ireland (5.29) & Denmark (4.11) & Netherlands (2.67) & Sweden (2.26) & Germany (1.26) \\
\hline $\mathbf{2 0 0 5}$ & Ireland (3.81) & Denmark (2.72) & Netherlands (1.72) & Sweden (1.44) & Sweden (0.78) \\
\hline $\mathbf{2 0 1 5}$ & Ireland (7.42) & Denmark (1.77) & Sweden (1.69) & Netherlands (1.49) & Croatia (1.26) \\
\hline
\end{tabular}

Under the second level the rating methodologies for countries brand assessment allow using the Spearman's rank correlation coefficient (2) to determine the strength and direction of the relationship between macroeconomic stability and the countries brand:

$$
\rho=1-\frac{6 \sum d_{i}^{2}}{n\left(n^{2}-1\right)}
$$

where, $\rho$ - Spearman's rank correlation coefficient, $d_{i}=x_{i}-y_{i}-$ the difference between the ranks of each observation from the two variables, $n$ - observations.

In order to study the relationship between macroeconomic stability and the country's brand, we have used two different approaches: 1) only the ten strongest national brands according to the rating of $\mathrm{NBI}$ since 2008 were considered (the beginning of the global financial and economic crisis). At the same time, 2016 was chosen to reflect the dynamic processes that had been taking place during 2008-2016 for understanding the level of macroeconomic stability of countries and the strength of national brands. 2) The data of the SIE rating in the EU and Ukraine (2010-2015) were taken into account. The rating data of the countries were used in both approaches in the quality of the "macroeconomic stability" sub-index of the Global Competitiveness Index of the World Economic Forum (The Global, 2016).

The calculation of the correlation between the rating of the World Economic Forum (MS) and the NBI national brands for the years 2008-2016 and the SVI for 2010-2015 subindex are presented in Tables 34.

\begin{tabular}{|c|c|c|c|c|c|c|c|c|}
\hline \multirow{2}{*}{ Country } & \multicolumn{4}{|c|}{2008} & \multicolumn{4}{|c|}{2016} \\
\hline & $\mathrm{NBI}\left(y_{i}\right)$ & MS $\left(x_{i}\right)$ & $d_{i}=x_{i}-y_{i}$ & $d_{i}^{2}$ & NBI $\left(y_{i}\right)$ & MS $\left(x_{i}\right)$ & $d_{i}=x_{i}-y_{i}$ & $d_{i}^{2}$ \\
\hline 1 & 2 & 3 & 4 & 5 & 6 & 7 & 8 & 9 \\
\hline USA & 7 & 8 & -1 & 1 & 1 & 7 & 6 & 36 \\
\hline
\end{tabular}

Table 3 - Ranking of the strongest national brands during 2008-2016 (The Global, 2016) 
Table 3

\begin{tabular}{|c|c|c|c|c|c|c|c|c|}
\hline 1 & 2 & 3 & 4 & 5 & 6 & 7 & 8 & 9 \\
\hline Germany & 1 & 1 & 0 & 0 & 2 & 3 & 1 & 1 \\
\hline Great Britain & 3 & 7 & -4 & 16 & 3 & 8 & 5 & 25 \\
\hline France & 2 & 6 & -4 & 16 & 5 & 6 & 1 & 1 \\
\hline Canada & 4 & 5 & -1 & 1 & 4 & 5 & 1 & 1 \\
\hline Japan & 5 & 9 & -4 & 16 & 7 & 10 & 3 & 9 \\
\hline Italy & 6 & 10 & -4 & 16 & 6 & 9 & 3 & 9 \\
\hline Switzerland & 8 & 3 & 5 & 25 & 8 & 1 & -7 & 49 \\
\hline Australia & 9 & 4 & 5 & 25 & 9 & 4 & -5 & 25 \\
\hline Sweden & 10 & 2 & 8 & 64 & 10 & 2 & -8 & 64 \\
\hline $\begin{array}{l}\text { Value of rank } \\
\text { correlation coefficient, } \rho\end{array}$ & \multicolumn{4}{|c|}{-0.09091} & \multicolumn{4}{|c|}{-0.33333} \\
\hline $\begin{array}{l}\text { The critically Spearman } \\
\text { correlation coefficient }\end{array}$ & \multicolumn{2}{|c|}{$0.64^{*}$} & \multicolumn{2}{|c|}{$0.79^{* *}$} & \multicolumn{2}{|c|}{$0.64^{*}$} & \multicolumn{2}{|c|}{$0.79^{* *}$} \\
\hline
\end{tabular}

${ }^{*}$ - statistically significant level $5 \%,{ }^{* *}$ - statistically significant level $1 \%$

Table 4 - Brands' ranking of EU countries and Ukraine during 2010-2015 (The Global, 2016)

\begin{tabular}{|l|c|c|c|c|c|c|c|c|}
\hline \multirow{2}{*}{ Country } & \multicolumn{3}{|c|}{$\mathbf{2 0 1 0}$} & \multicolumn{4}{c|}{$\mathbf{2 0 1 5}$} \\
\cline { 2 - 10 } & $\mathbf{C B I}\left(\boldsymbol{y}_{\boldsymbol{i}}\right)$ & $\mathbf{M S}\left(\boldsymbol{x}_{\boldsymbol{i}}\right)$ & $\boldsymbol{d}_{\boldsymbol{i}}=\boldsymbol{x}_{\boldsymbol{i}}-\boldsymbol{y}_{\boldsymbol{i}}$ & $\boldsymbol{d}_{\boldsymbol{i}}^{\mathbf{2}}$ & $\mathbf{C B I}\left(\boldsymbol{y}_{\boldsymbol{i}}\right)$ & $\mathbf{M S}\left(\boldsymbol{x}_{\boldsymbol{i}}\right)$ & $\boldsymbol{d}_{\boldsymbol{i}}=\boldsymbol{x}_{\boldsymbol{i}}-\boldsymbol{y}_{\boldsymbol{i}}$ & $\boldsymbol{d}_{\boldsymbol{i}}^{\mathbf{2}}$ \\
\hline Sweden & 4 & 2 & -2 & 4 & 2 & 3 & 1 & 1 \\
\hline Germany & 5 & 1 & -4 & 16 & 1 & 4 & 3 & 9 \\
\hline Finland & 2 & 3 & 1 & 1 & 6 & 9 & 3 & 9 \\
\hline United Kingdom & 3 & 14 & 11 & 121 & 5 & 19 & 14 & 196 \\
\hline Denmark & 9 & 4 & -5 & 25 & 3 & 1 & -2 & 4 \\
\hline France & 1 & 10 & 9 & 81 & 8 & 16 & 8 & 64 \\
\hline Italy & 6 & 19 & 13 & 169 & 9 & 20 & 11 & 121 \\
\hline Austria & 10 & 6 & -4 & 16 & 4 & 7 & 3 & 9 \\
\hline Netherlands & 12 & 7 & -5 & 25 & 7 & 6 & -1 & 1 \\
\hline Spain & 7 & 16 & 9 & 81 & 12 & 21 & 9 & 81 \\
\hline Ireland & 8 & 21 & 13 & 169 & 10 & 17 & 7 & 49 \\
\hline Belgium & 14 & 18 & 4 & 16 & 11 & 15 & 4 & 16 \\
\hline Portugal & 13 & 22 & 9 & 81 & 13 & 22 & 9 & 81 \\
\hline Malta & 17 & 13 & -4 & 16 & 16 & 11 & -5 & 25 \\
\hline Greece & 11 & 23 & 12 & 144 & 15 & 23 & 8 & 64 \\
\hline Croatia & 16 & 12 & -4 & 16 & 17 & 18 & 1 & 1 \\
\hline Czech Republic & 15 & 11 & -4 & 16 & 14 & 5 & -9 & 81 \\
\hline Estonia & 22 & 5 & -17 & 289 & 19 & 2 & -17 & 289 \\
\hline Hungary & 18 & 17 & -1 & 1 & 20 & 13 & -7 & 49 \\
\hline Slovakia & 20 & 8 & -12 & 144 & 21 & 10 & -11 & 121 \\
\hline Poland & 21 & 15 & -6 & 36 & 18 & 12 & -6 & 36 \\
\hline Bulgaria & 19 & 9 & -10 & 100 & 23 & 14 & -9 & 81 \\
\hline Romania & 23 & 20 & -3 & 9 & 22 & 8 & -14 & 196 \\
\hline Ukraine & 24 & 24 & 0 & 0 & 24 & 24 & 0 & 0 \\
\hline $\begin{array}{l}\text { Value of rank correlation } \\
\text { coefficient, } \boldsymbol{\rho}\end{array}$ & \multicolumn{2}{|c|}{0.311304} & & & 0.314783 & \\
\hline $\begin{array}{l}\text { The critically } \\
\text { correlation coefficient }\end{array}$ & $0.41^{*}$ & & $0.52^{* *}$ & & & $0.41^{*}$ & & $0.52^{* *}$ \\
\hline
\end{tabular}

${ }^{*}$ - statistically significant level $5 \%,{ }^{* *}$ - statistically significant level $1 \%$ 
The insignificant level of the rank correlation coefficient for both models explains primarily due to different positions in the ratings in most of the countries under study. In the case of the first approach, the existence of a linear relationship between the level of macroeconomic stability and the strength of the national brand was observed. Such tendency is typical for Germany, France, Canada, and the other Sweden, Germany, Finland, Denmark, Austria, the Netherlands, Croatia, Ukraine. Special attention deserves the countries, which, along with the support of macroeconomic stability, ensured the growth of their branding programs (Sweden, Germany, Denmark, Austria).

Since independence, In Ukraine only in 2003 , the government had made the first attempts to introduce the country's marketing in order to improve the negative situation associated with the competitive position and image of the country. Thus, on October 15, 2003, the Cabinet of Ministers of Ukraine adopted the "State Program for the Positive International Image of Ukraine for 2003-2006". This program envisaged "the creation of an external information atmosphere necessary for the implementation of internal political and socio-economic transformations, efficient information support of the foreign policy for European and Euro-Atlantic integration, creating conditions for building of trust in the political, cultural and economic spheres in Ukraine, strengthening of the coordination of the executive authorities aimed to ensure Ukraine's informational presence abroad, the nationalization of the state legislation in line with European and global standards. "

Positive internal image of the state is able to decrease the vulnerable actions of destabilizing factors of the environment and according to Hurkovskii (2012) "To unite the nation in order to ensure constant purposeful social development and to strengthen the self-identification of the population as a single people, the community irrespective of ethnic origin and property status of its constituent subjects" (Hurkovskyi, 2012).

One of the strategic indicators of the implementation of the Ukraine-2020 Sustainable Development Strategy is the entry into the top 40 countries of the world by the Global Competitiveness Index (Sustainable, 2015). One of the significant condition of ranking in such system is providing of green investment strategies in Ukraine (Chygryn, 2015). According to the Global Competitiveness Report (Table 5), Ukraine ranks average of 81 (estimated at 4.06) in the world for the last five years. Furthermore, the analysis of the variation indicated by the indicator does not exceed $33 \%$, which makes it possible to characterize this population as a homogeneous (Dziubanovska, 2016), but does not provide the appropriate dynamics for improving the global competitiveness of the country.

Table 5 - Change in indicators of international competitiveness of Ukraine (The Global, 2016)

\begin{tabular}{|c|c|c|c|c|c|c|}
\hline & \begin{tabular}{|c|}
$2013-2014$ \\
Rank (from \\
48 countries) / \\
Score (1-7) \\
\end{tabular} & \begin{tabular}{|c|}
$2014-2015$ \\
Rank (from \\
44 countries) I \\
Score (1-7)
\end{tabular} & \begin{tabular}{|c|}
$2015-2016$ \\
Rank (from \\
40 countries) $/$ \\
Score (1-7) \\
\end{tabular} & \begin{tabular}{|c|}
$2016-2017$ \\
Rank (from \\
38 countries) $/$ \\
Score (1-7) \\
\end{tabular} & $\begin{array}{l}\text { Average } \\
\text { value } \\
\text { Rank/ } \\
\text { Score } \\
\end{array}$ & $\begin{array}{l}\text { Standard } \\
\text { deviation } \\
\text { Rank/ Score }\end{array}$ \\
\hline 1 & 2 & 3 & 4 & 5 & 6 & 7 \\
\hline $\begin{array}{l}\text { Global Competitiveness } \\
\text { Index }\end{array}$ & $84 / 4.1$ & $76 / 4.1$ & $79 / 4.0$ & $85 / 4.0$ & $81 / 4.06$ & $3.67 / 0.05$ \\
\hline State institutions & $137 / 3.0$ & $130 / 3.0$ & $130 / 3.1$ & $129 / 3.0$ & $129 / 3.06$ & $6.83 / 0.09$ \\
\hline Infrastructure & $68 / 4.1$ & $68 / 4.2$ & $69 / 4.1$ & $75 / 3.9$ & $72 / 4.04$ & $4.62 / 0.13$ \\
\hline Macroeconomic stability & $107 / 4.2$ & $105 / 4.1$ & $134 / 3.1$ & $128 / 3.2$ & $119 / 3.62$ & $12.75 / 0.51$ \\
\hline $\begin{array}{l}\text { Health care and } \\
\text { elementary education }\end{array}$ & $62 / 5.8$ & $43 / 6.1$ & $45 / 6.1$ & $54 / 6.0$ & $51 / 6.0$ & $7.64 / 0.122$ \\
\hline $\begin{array}{l}\text { Higher education and } \\
\text { vocational training }\end{array}$ & $43 / 4.7$ & $40 / 4.9$ & $34 / 5.0$ & $33 / 5.1$ & $37 / 4.96$ & $4.30 / 0.17$ \\
\hline $\begin{array}{l}\text { Efficiency of commodity } \\
\text { markets }\end{array}$ & $124 / 3.8$ & $112 / 4.0$ & $106 / 4.0$ & $108 / 4.0$ & $110 / 3.96$ & $8.67 / 0.09$ \\
\hline Labor market efficiency & $84 / 4.2$ & $80 / 4.1$ & $56 / 4.3$ & $73 / 4.2$ & $76 / 4.16$ & $12.13 / 0.11$ \\
\hline
\end{tabular}


Table 5

\begin{tabular}{|l|c|c|c|c|c|c|}
\hline \multicolumn{1}{|c|}{1} & 2 & 3 & 4 & 5 & 6 & 7 \\
\hline $\begin{array}{l}\text { Development of financial } \\
\text { markets }\end{array}$ & $117 / 3.5$ & $107 / 3.5$ & $121 / 3.2$ & $130 / 3.0$ & $119 / 3.26$ & $8.28 / 0.23$ \\
\hline technological availability & $94 / 3.3$ & $85 / 3.5$ & $86 / 3.4$ & $85 / 3.6$ & $86 / 3.52$ & $4.76 / 0.19$ \\
\hline Market volume & $38 / 4.6$ & $38 / 4.6$ & $45 / 4.5$ & $47 / 4.4$ & $43 / 4.52$ & $4.64 / 0.08$ \\
\hline $\begin{array}{l}\text { Compliance with modern } \\
\text { business requirements }\end{array}$ & $97 / 3.7$ & $99 / 3.7$ & $91 / 3.7$ & $98 / 3.6$ & $95 / 3.68$ & $4.2 / 0.04$ \\
\hline Innovations & $93 / 3.0$ & $81 / 3.2$ & $54 / 3.4$ & $52 / 3.4$ & $68 / 3.28$ & $17.99 / 0.18$ \\
\hline
\end{tabular}

Implementation of the national branding program positively influenced on the country's level of competitiveness. In 2003-2006, according to the rating of the WEF, Ukraine's competitive position changed from 86th to 73rd (The Global, 2016). As regards to the macroeconomic outcomes of the program, which should have included foreign investment, employment growth, export expansion, Ukraine, according to these criteria, declined from the 76 th to the 82 nd place in the world ranking. Thus, the value of exports to the value of imports in the period from 2003 to 2006 decreased by $10.41 \%$ (from $104.66 \%$ in 2003 to $94.24 \%$ in 2006) and was less than $100 \%$, which means the imbalance of foreign trade countries. During the whole period, since 2006, the foreign trade balance of Ukraine has become negative, and on average, from 2003 to 2016, it was -9957.5 million USD.

One of the main limiting factors for increasing competitiveness was the macroeconomic stability of the national economy, which in the last 14 observations had an upward trend (Figure 3).

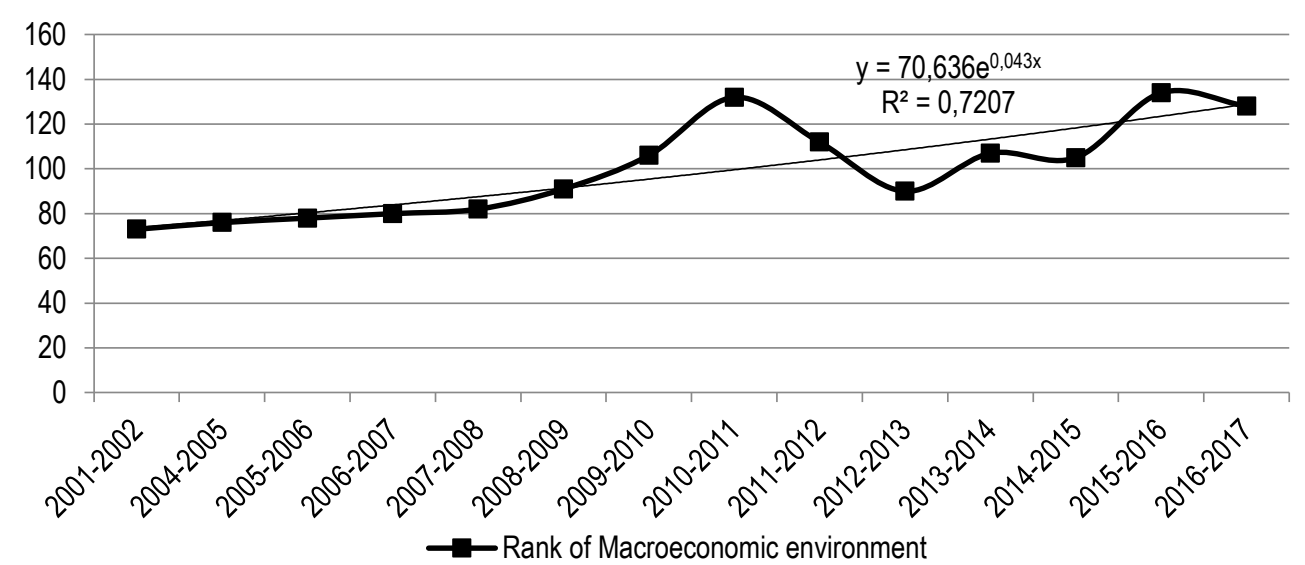

Figure 3 - Trend of changes of the sub-index "macroeconomic stability" for Ukraine in the period from 2000-2016 (The Global, 2016)

In 2007, the state program for ensuring a positive international image of Ukraine was revised and adopted for 2007-2010 and extended to 2008-2011. Assessing the Concept of the State Target Program for the Formation of Positive International Image of Ukraine for 2008-2011, it can be argued that this project, despite on its orientation towards improving the competitive position of Ukraine, was too general. There wasn't specific action and a description how these measures should be implemented. This program meant improving the state's economy by simultaneously attracting foreign investment, increasing the trust of domestic enterprises from potential partners, activating business contacts, increasing export volumes, activating international tourism activities, and raising the level of employment and welfare of Ukrainian 
citizens (Concepts, 2007). Unfortunately, this program hadn't received a priority in Ukraine's' state policy. That is why influenced by the impact of the global financial and economic crisis Ukraine had lost in 2011 8 positions on the rating of macroeconomic stability compared to 2006.

The soaring inflation in Ukraine's economy and declining of economic growth hadn't allowed the government to allocate sufficient funds for the implementation of the "State target program for the formation of a positive international image of Ukraine for the period up to 2011", which radically differed from the previous documents by conceptual clarity, clear plan of action (Hnatiuk, 2009).

Under globalization formation of the state's image and increasing of competition should be based on summing up the reactions and background of the all stakeholder groups of the country for many years of experience with it. Also should be considered in the round the experience of country visiting or residence in it. This approach allows differentiated of views on the state image and to distinguish the internal and external image of the country. The concept of an internal image is closely linked with the identity and it expresses first of all what the inhabitants think about their country. Further, the external image reflects the issue of macroeconomic stability of the country and its perception in the global environment. At the same time, "macroeconomic stability" should be considered on the basis of two main aspects: firstly, as the condition in which the balance between the level and the growth of key macroeconomic variables is stable, the variability of macroeconomic variables is temperate and falls within an acceptable range, there is no complete uncertainty about the macroeconomic environment; and secondly, as a process of preventing and eliminating threats to economic growth in order to meet the growing needs of economic entities in the conditions of limited resources.

Conclusions. The presented empirical results confirmed the hypothesis that it is impossible to use a purely behavioural model of brand assessment to study its impact on the macroeconomic stability of the country. It was found that one of the main drawbacks of such models is the subjective nature of the assessment of the brand target audience's relation to the countries concerned and choosing the factors used to explain the brand's strength or its value formation and completely ignore the important aspects of the business (financial aspects and strategic prospects of the country's economic development).

In turn, the analysis of the Global Competitiveness Index of Ukraine has shown that the existing trends of subindices are not in line with one of the strategic indicators of the Ukraine-2020 Sustainable Development Strategy implementation what will could ensured the entry into the top 40 countries of the world by the Global Competitiveness Index. The steadiest dynamics, which is characterized by a slight variation of signs, within $10 \%$, according to the rank and the assessment in the rating of the Global Competitiveness Index of Ukraine, have got state institutions, infrastructure, commodity market efficiency, development of financial markets, technological availability and compliance of business with modern requirements. However, the average rank of the majority of these components of the Ukrainian Competitiveness Index was estimated as weak: state institutions - 129th place, an efficiency of commodity markets - 110th place, development of financial markets - 119th place, compliance of business with modern requirements - 95th place, technological availability - 86th place. At the same time, state institutions, macroeconomic stability and the development of financial markets became the most constraining components of the growth of Ukraine's rating in 2016. The above-mentioned determine the necessity to search for absolutely new factors and tools for increasing the competitiveness of the country. In particular, the marketing factors of creating competitive advantages have become relevant.

Anholt, S. (1998). Nation-Brands of the Twenty-First Century. Journal of Brand Management. 5(6), 395-406.

Anholt, S. (2005). Brand New Justice" How Branding of new Places and Products Can Help The Developing World, Revised Edition, Butterworth-Heinemann, pp: 94 $732 p$

Anholt, S. (2007). Competitive Identity: The New Brand Management for Nations, Cities and Regions, Palgrave Macmillan, 
Belloso, J. (2010). Country brand. A differentiation mechanism and source of intangibles. Paradigmes: economia productiva i coneixement. 6(5). 42

Chygryn, O., Krasnyak, V. (2015). Theoretical and applied aspects of the development of environmental investment in Ukraine. Marketing and Management of Innovations. 3, P. 226-234.

Concepts of the State Target Program for the Formation of Positive International Image of Ukraine for 2008-2011. (2007) Retrieved from http://zakon0.rada.gov.ua/laws/show/379-2007-\%D1\%80

Costa, R., Evangelista S. (2008). An AHP approach to assess brand intangible assets. Measuring Business Excellence. 12. 2. 68-78.

Dinnie, K. (2008). Nation branding: Concepts, issues, practice. Oxford: Butterworth-Heinemann, 399 p.

Dziubanovska, N. (2016). Approach to the comparative analysis of international trade of the European Union. Black Sea Economic Studies. 11. 245-250.

Fedoriv, T. (2011). Correlation of the concepts of "image" and "reputation" in the state. Bulletin NADU. 2. 25-29.

Fetscherin, M. (2010). The determinants and measurement of a country brand: the country brand strength index Retrieved from https://scholarship.rollins.edu/cgi/viewcontent.cgi?article=1043\&context=as_facpub

Hankinson, G. (2001). Location Branding: A Study of the Branding Practices of 12 English Cities. Journall of Brand Management 9(2), 127-142. 75.

Hanna, S., Rowley, J. (2008). An analysis of terminology use in place branding. Place branding and public diplomacy. 4(1). 61 .

Hnatiuk, S. (2009). Formation of a positive international image of the Ukrainian state in the information space. Official website of the National Institute for Strategic Studies. Retrieved from http://old.niss.gov.ua/Monitor/December2009/02.

Hurkovskyi, V. (2012). Protection of the image of the Ukrainian state in the conditions of informational globalization. Public Administration: Theory and Practice. 2. Retrieved from http://nbuv.gov.ua/UJRN/Dutp_2012_2_11

laremko, Z., Tkach,G. (2016). Concerning the national branding in Ukraine in the context of promoting its interests in the world. Young. 40(12.1). 1035-1040.

Jaffe, E. (2001). National Image and Competitive Advantage - The Theory and Practice of Country-of-Origin Effect. Copenhagen Business School Press $186 \mathrm{p}$.

Keller, K. (2003). Strategic Brand Management: Building, Measuring, and Managing Brand Equity, 2nd edition, Upper Saddle River, NJ: Prentice Hall, New Jersey.

Kotler, P., Asplund, C., Rein, I., \& Haider, D. (1999). Marketing Places Europe: attracting investments, industries, residents and visitors to European Cities, Communities, Regions and Nations. London: Pearson Education Ltd.

Kotler, P., Gertner, D. (2002). Country as a brand, product and beyond: a place marketing and brand management perspective. Journal of Brand Management. 9(4-5). 249-261.

Krykun, V. (2010). Methodological aspects of the concepts "trademark", "brand", "goodwill". Management and sustainable development. №2. 144-146.

Lyulyov, O. (2016). Determinants of Macroeconomic Stability: An Analysis of International Approaches and Dynamics of Indicators in Ukraine. Bulletin SSU. Economy. 3. 7-4.

Morgan, N., Pritchard, A., \& R. Piggott. (2002). New Zealand, 100\% Pure: The Creation of a Powerful Niche Destination Brand. Journal of Brand Management, 9 (4-5), 335-354.

Murpy, L., Moscardo, G., \& Beckendorff, P. (2007). Using Brand Personality to Differentiate Regional Tourism Destinations. Journal of Travel Research 46(5), 5-14.

Rassomakhina, O. (2007). The concept of a trademark and its relationship with related categories. Law Forum. 3. 212-223.

Riege, A. M., \& Perry, C. (2000). National marketing strategies in international travel and tourism. European Journal of Marketing, 34(11/12), 1290-1305.

Sustainable Development Strategy "Ukraine 2020" (2015). Retrieved from http://zakon.rada.gov.ua/laws/show/5/2015 The Global Comhetitiveness Report (2016). World Economic Forum, Geneva. Retrieved from http//www.weforum.org Tsyhankova, T., Zavhorodnia, T. (2011). The global brand of the country in modern technologies of trade and marketing activity. Intarnational economic policy. 1-2. 5-31.

Ward, S. V. (1998). Selling Places: The marketing and promotion of towns and cities 1850- 2000. London: E \& FN Spon

Warnaby, G., Bennison, D., Davies, B.J., \& Hughes, H. (2002). Marketing UK Towns and Cities as Shopping Destinations. Journal of Marketing Management 18(9-10), 877-904.

Wood, L. (2000). Brands and brand equity: definition and management. Management decision, 38(9), 662-669.

О. В. Люльов, к.е.н., доцент, Сумський державний університет (Суми, Україна);

О. Ю. Чигрин, к.е.н., доцент, Сумський державний університет (Суми, Україна);

T. В. Пімоненко, к.е.н., доцент, Сумський державний університет (Суми, Україна).

Національний бренд як маркетингова детермінанта макроекономічної стабільності

Сучасні тенденції глобалізації та зростання конкурентоспроможності держав змушують уряди шукати нові підходи та відповідні інструменти для підвищення їх конкурентних можливостей. Дослідження пояснює, чому маркетингові 


\section{O. Lyulyov, O. Chygryn, T. Pimonenko. National Brand as a Marketing Determinant of Macroeconomic Stability}

фактори формування конкурентних переваг сьогодні мають нагальну важливість для формування та обгрунтування маркетингових стратегій міст та муніципалітетів, регіонів та територіальних громад, країн в цілому. Метою статті $\epsilon$ вивчення маркетингових факторів формування конкурентних переваг країни та визначення впливу національного бренду на макроекономічну стабільність держави. В статті висунуто гіпотезу про наявність зв'язку між сприйняттям бренду країни нерезидентами та макроекономічними індикаторами результативності використання країною її бренду. Для перевірки справедливості цієї гіпотези розроблено дворівневий підхід. Рівень 1 передбачає оцінювання економічноі результативності використання країною ії бренду, з урахуванням здобутих країною конкурентних переваг в глобальному середовищі, орієнтований на ретроспективні оцінки на тривалому часовому горизонті, містить композитні індикатори, які є об'єктивними та кількісно вимірюваними за єдиною міжнародною методологією, базується на методології PESTLE-аналізу. Рівень 2 передбачає оцінювання ( за допомогою методу рангової кореляиії Сnірмена) непараметричної міри статистичної залежності між зовнішнім сприйняттям країни нерезидентами (визначається за методологією компанії FutureBrand, що базується на опитуваннях груп респондентів: зовнішніх інвесторів, туристів, урядів інших держав тощо) та економічною результативністю використання країною їі бренду. Емпіричне підтвердження иієї гіпотези здійснено на двох вибірках даних. Перша база статистичної інформації охоплювала лише десять найсильніших наиіональних брендів за рейтингом NBI з 2008 року. Розрахунки підтвердили існування лінійного взаємозв'язку між рівнем макроекономічної стабільності та силою національного бренду для Німеччини, Франції, Канади. Основу другої бази статистичної інфоормації склали дані рейтингу SIE в ЄC та Україні у 2010-2015 рр. За розрахунками гіпотеза дослідження підтвердилася для Швеції, Німеччини, Фінляндії, Данії, Австрії, Нідерландів, Хорватії, України.

Ключові слова: бренд, імідж країни, конкурентоспроможність, стійкість, репутація країни. 